\title{
Students' Perceptions toward Using YouTube in EFL Classrooms
}

\author{
Geminastiti Sakkir ${ }^{\mathrm{a}, *}$, Syarifuddin Dollah ${ }^{\mathrm{b}}$, Jamaluddin Ahmad ${ }^{\mathrm{c}}$ \\ ${ }^{a, b}$ Universitas Negeri Makassar, Jalan Dg. Tata Raya, Makassar 90224, Indonesia, hj.geminastitisakkir@yahoo.com \\ ${ }^{a, c}$ Universitas Muhammadiyah Sidenreng Rappang, Jalan Angkatan 45 No. 1A, Sidrap 91651, Indonesia
}

\begin{abstract}
The using of videos from YouTube channel in the EFL classroom is imperative to fill the educational needs of the younger generation. Although resources from textbook have remained the standard for centuries, currently, with the fast pace of the development of technology, the usage of YouTube videos in teaching and learning has become a trend. There are a few studies conducted on students' perceptions of using YouTube to learn the English language. The objective of this research was to investigate the students' perceptions on the use of YouTube in learning English process at English Education Department, Universitas Negeri Makassar Indonesia. Data were collected using a questionnaire that collected background information of participants and a five-point Likert scale to gauge the students' perception use of the YouTube in EFL classroom. Findings from this research indicate that the majority of students showed a positive perception toward and a willingness to use YouTube in the EFL classroom. It was also discovered that the students have used YouTube to help them completed their course assignments and study tasks. Hence, it can be concluded that the students preferred to use English YouTube videos to help them enhance their English language level proficiency.
\end{abstract}

(C) 2020 Author(s). All rights reserved.

Keywords: YouTube; perceptions; interest; learning style; EFL learners

\section{Introduction}

Today is the era of digital technology where the new generation uses internet technology in all aspects of their lives. Due to the arrival of this technical literacy people, their learning style is differing from the previous generations. Thus, this lead to an integrated approach and a paradigm shift in teaching which have witnessed an adoption of a new method of teaching using YouTube videos in the classroom. This approach has brought new insights to pedagogy in higher institution and it is believed that the use of YouTube as a teaching tool could have an effect on the level of student engagement. The use of YouTube, social media and other Web 2.0 technologies in education has been proposed as a tool to engage new generation students [1]; [2]; [3]; [4]; [5].

YouTube has become an important tool in many universities and colleges around the world. According to [6], MySpace, Facebook and YouTube are the top three favorable websites for university students. Therefore, the emergence of digital technologies such as internet and the worldwide web has made the use of YouTube in classroom a possibility. Today, the new technology has provided a lot of opportunities to improve the qualities of teaching and

\footnotetext{
* Corresponding author.

E-mail address: hj.geminastitisakkir@yahoo.com (Geminastiti Sakkir)
} 
learning such as the use of internet, social media and YouTube videos. Most of Indonesia university students take these media to help them do their assignments or homework and other language learning tasks. Then, this media helped them to learn English as well as improve their proficiency level. YouTube is featured as something very authentic and able to help the students because it has been reported that the lack of English language proficiency has often been mentioned as one of the major factors contributing to graduate unemployment [7]. How students learn and gain information from YouTube in learning English as EFL is very important because it will help the lecturers to identify the students' preference, interest and types of material that they use to enhance learning. Therefore, by using a variety of instructional methods and learning activities in the classroom or via online education can help enrich the learning environment of the students [8].

Since the use of YouTube videos to learn English language is still a new idea, how it can be used in facilitating language learning in class effectively is still unclear. [9] explained that a study on the perception of the usage of YouTube in ESL classroom for undergraduate students is a relatively new field of study and not much literature has been published regarding the subject. Despite the importance of using YouTube in engaging students in the classroom, little research has been conducted to investigate the perceptions of Indonesia undergraduate in using YouTube in EFL classroom. The objective of the research is to investigate the use of YouTube in the EFL classroom by surveying students' perceptions towards using YouTube to learn English. In particular, it seeks to look at the students' perceptions of using YouTube as a supplement to other learning materials with regard to making classes more interesting and motivating for students to use materials to learn English outside of the class [10]. In short, the research question was as follows: "What are the students' perceptions of using YouTube in the EFL classroom?"

\section{Literature Review}

\subsection{Technology as a Tool for Learning English}

Rahmhan Sakkir \& Khalik [11] stated that although the schools are embedded in culture and reflect its values, the technological changes that have swept through society at large have left the educational system largely unchanged. Laptop, video and other technologies, engage children with the immediacy they are used to in their everyday lives. With the arising awareness of the theory associated with learning and a arising interest in the ways that new technologies might change the way that teachers teach and children learn, there is scope, perhaps even a real need, to look at what is currently known about learning, especially in relation to the new possibilities afforded by Information and Communications Technologies [12].

Technology is a tool that it utilized to support the learning of various students, and the EFL classroom is no exception. In particular, educators shave showed that the use of audio blogs contributes to enhanced opportunity to practice English speaking skills in the classroom [11]. Offering students spoken assignments offers the educator a greater opportunity to assess the speech development of students, and the methods applied could be tailored to meet the needs of various students. Students could use their cell phones for these recorded tasks, demonstrating that there is a low technology barrier to this practice. The students are prompted to answer question in a range of forms, including interviews, surveys, and open-ended questions, and the accessibility of their corded blogs makes this too easier for the educator to assess the quality of English used by his or her students.

More technological devices exist to allow for the learning of English through in deed. Actually, one technique that has been applied is the use of taking pictures along with phrases to identify the subjects associated with photos in the English language. This technique is advantageous because it offers students the ability to describe images that are captured through the use of cell phone technology, cameras, or social media, and this will help them therefore associate their knowledge of these subjects with their existing knowledge and promote the learning process [5]. This system has been shown to be more effective for people who do use these mobile-assisted language learning techniques compared to those who don't. Although improvement may only be due to increased engagement, the statistics demonstrate that this technique does improve the quality of English language learning. 


\subsection{YouTube and other ICT tools in EFL classrooms}

Research into the use of YouTube in the EFL classroom is a relatively new area of study. However, the use of YouTube and other ICT tools in language learning has become a popular discussion all over the world. Several scholars from different countries suggested that using ICT in the classroom is becoming more prevalent in coming years [13]; [14]. In Indonesia, the phenomena of using ICT, such as social media and YouTube, allows students to learn actively and interactively in the classrooms and is acknowledged and considered as one of the most significant changes in EFL classroom. The youth today use technology like the internet more than any other methods as a medium of communication and socialization. Therefore, due to this reality, educators bring in YouTube into the classroom to suit with the students' preferences and interest thus will make learning more interesting [15].

The use of YouTube has given positive impacts to the students' motivation. As stated by [16], videos can have a strong effect on their minds and senses. He also suggested that the use of video clips need to be inserted in multimedia presentation to improve learning in higher educational institutions. These included using videos to grab students' attention, improve students' concentration, generate interests in the lesson, improve attitudes towards content, draw on students' imagination and make learning fun and meaningful. [16] also claimed that YouTube videos are not only able to attract the students' attention, but can cater different learning styles namely verbal, visual, musical, and emotional intelligences. Watching videos also allowed the brain to react actively to both side of the brain which helps to increase and enhance students' understanding. Students' motivation to learn is much relies on their learning styles. According to [17] have proposed that the definition of 'learning styles' is characteristic cognitive, effective and psychosocial behaviors that serve as relatively stable indicators of how learners perceive, interact with and respond to the learning environment. Many scholars have introduced different models of learning styles, one of them is Walter Burke Barbe which proposed three learning modalities known as VAK a) visual, b) auditory and kinesthetic learning and this model is a mixture of preferences, strengths and personality which is a mixture in each individual.

Another research was conducted by [18] which was a study on using YouTube as a tool to support collaborative learning. The study was conducted on a first year of IS course at the University of Pretoria. The course included a group project in which students used YouTube to create a video on how businesses can use Web 2.0 technologies amongst other tasks. It was reported that from a sample of 185 students, it was found that YouTube was perceived as an innovative learning technology by the majority of the students. [19] agreed that the use of YouTube videos helped students to explain key ideas in a sociology course. They used these videos in an introductory sociology course at the Foundation Centre at Durham University. [19] used these videos to illustrate important topics by giving explanation and discussion in the class and in smaller group environments. They also further explained that the use of YouTube videos helped students and was seen as an effective way to support their learning. In conclusion, as educators consider the use of YouTube video as important, thus, they must strongly consider what students' think and feel about these tools in their courses.

\subsection{The Use of YouTube for Learning English}

YouTube has been used as a tool for the purpose of improving the English-speaking skills of students. In particular, an action research study that evaluated the use of this technique on seventh grade students could that there was an overall improvement in the students' speaking skills after applying this intervention. In particular, [20] found that knowledge of content, grammar, pronunciation, vocabulary, and fluency improved for those who had participated. This technique has also been applied to support the English-speaking skills of 11th grade students in Portugal [21]. The authors concluded that the use of YouTube and related learning strategies contributes value to the classroom. In particular, this is an additional mode through which students could be exposed to the language-based material that they are learning, and YouTube may make the experience more meaningful for them because this allows their interests to be captured. 
At the university level, research has demonstrated that groups who participate in watching YouTube videos to assist them during a reading activity were more likely to receive better scores compared to students who did not participate in the intervention. Vocabulary achievement was a long-term effect associated with this outcome [22]. Another advantage is that YouTube videos could be used to educate students about some of the diversity that appears in English speaking across the world to better prepare them for some of the social situations that they may find themselves in [22].

\section{Method}

This research is descriptive and use a quantitative method consisted of a questionnaire- based survey which is administered to undergraduate students. The questionnaire consisted of two parts. The first part of the questionnaire included demographic information of the respondent including gender, age, levels of language proficiency and year of research, YouTube content, frequency and duration in access the YouTube every day. The second part consisted of twenty questions using Likert- scale which related to the students' perception toward using YouTube in EFL classroom. Questionnaire was constructed to answer the research question which is the perceptions of university's students of using YouTube in the classroom. The sample of the research $(n=76)$ is the first semester undergraduate students from Faculty of Language and Literature, English Education Department, Universitas Negeri Makassar, Indonesia. The questionnaires made use of the Likert scale ranging from 1= Strongly Disagree, 2= Disagree, $3=$ Undecided, 4= Agree and 5= Strongly Agree. Neag Centre for Gifted Education and Talent Development University of Connecticut (2007) states that perception affects emotions and behaviours and the emotional and behavioural reactions also help shape the environments and skew ones' beliefs about their environments. Questionnaire for the students give to know their feeling, opinion and thought using the media. The data from the questionnaire were analyzed by using Likert Scale. It aimed to measure the students' opinion. The answering each instrument items of Likert Scale that divided into positive statements and negative statements as follows:

Table 1. Likert scale

\begin{tabular}{lll}
\hline Positive statement scores & Category & Negative statement score \\
\hline 5 & strongly agree & 1 \\
4 & agree & 2 \\
3 & undecided & 3 \\
2 & disagree & 4 \\
1 & strongly disagree & 5 \\
\hline
\end{tabular}

To interpret the students' interest responds, the researcher used the interval estimate. The interval estimation was used to measure the parameter of population based on the score of rates interval sample data that has 15 intervals estimate each level. In this case, the rating score was ranged 20 to 100 and the questionnaire levels were 5 levels or 5 categories. Thus, the researcher started to measure the score of strongly disagree (20) to strongly agree (100). Therefore, the researcher used 15 intervals estimate and as well as large enough score in order to minimize the error level or insignificant scores in measuring.

The interval of the students' perceptions responds on the questionnaire can be seen in the table 2 .

Table 2. Rating score of perceptions category

\begin{tabular}{ll}
\hline Score & Category \\
\hline $84-100$ & Strongly positive (very high) \\
$68-83$ & Positive (high) \\
$52-67$ & Moderate (average) \\
$36-51$ & Negative (low) \\
$0-35$ & Strongly negative (very low) \\
\hline
\end{tabular}

To calculate questionnaire data into percentage, the researcher used the percentage technique using this formula. The formula used in analyzing the data as follows: 


$$
\mathrm{P}=\frac{F q}{N} \times 100 \%
$$

Where:

$\mathrm{P} \quad=$ Percentage from test and questionnaire

$\mathrm{F} \mathrm{q} \quad=$ Number of Frequency

$\mathrm{N} \quad=$ Total Samples

\section{Findings and Discussions}

In the findings, the data was analyzed; the students' responses from the question were tabulated and discussed in later chapters. The results show that out from 76 students, $76.32 \%(n=58)$ of the students were female and $23.68 \%(n=18)$ male. Females were the majority of the samples. The students' age ranged from 17-22 years of age with the majority of students being 18 (55.26\%), 19 (25\%), 17 (13.16\%), 20 (5.26\%) and 22 above only (1.32\%) years of age. All of the population $(\mathrm{n}=76)$ were first semester students of English Education Department, Universitas Negeri Makassar, South Sulawesi, Indonesia. The data also revealed that most of the students rated themselves as possessing an beginners level of English proficiency level with $(n=59)$ whereas the advanced students comprise of $13.16 \%(n=10)$ and the intermediate proficiency levels were only $9.21 \%(n=7)$. Thus, it can be concluded that most of the students possessed Basic English proficiency levels.

\section{English Proficiency Levels}

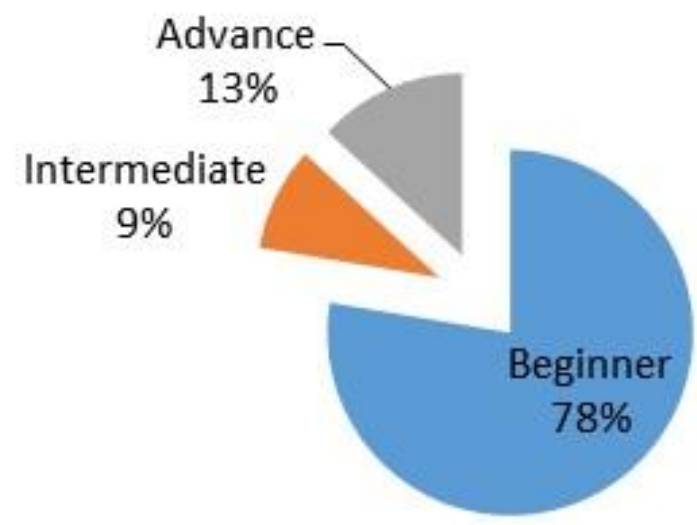

Figure 1. English Proficiency Levels of students

The data also showed that most of the students opened entertainment content (42.10\%) and songs (28.95\%), lesson content in the third position $(18.42 \%)$, movie program (9.21\%) and the last games just $1.32 \%$.

Fortunately the students access the content in English version (55.26\%) more than in Indonesian language (44.74\%), its mean that the students can make the YouTube as a medium to learn English directly and unconsciously. The frequency of the students access the YouTube every day 1-2 times (42.10\%), 3-4 times (40.79\%) and few of them access it every time (17.11\%). The duration every time the students access YouTube around 1-2 hours (57.89\%), 2-3 hours (22.36\%), 3-5 hours (13.17\%) and there are 6.58\% (5 students) access YouTube more than 5 hours. 
Therefore to evaluate whether this method is effective to be used, the students responses are gathered. In this phase, the researcher provides questionnaires to the students, in order to gather their response with regard to the practicality and the effectiveness of the YouTube to be used in the process of teaching and learning in EFL classroom.

To know the students' perception toward the implementation of YouTube, the researcher distributed questionnaire to the students. The data was analyzed by using Likert Scale. The results show the students have positive perception in using YouTube. This is indicated by the percentage of the students' questionnaire shown in the table 3.

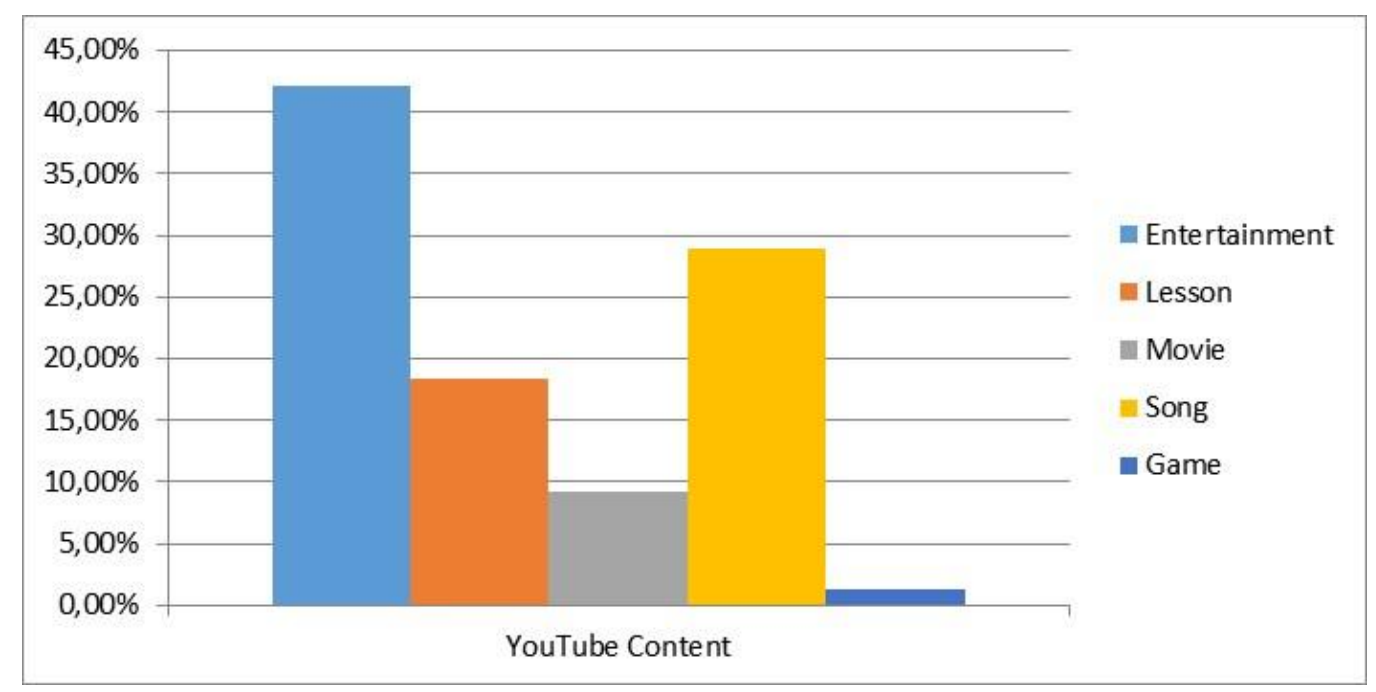

Figure 2. YouTube Content

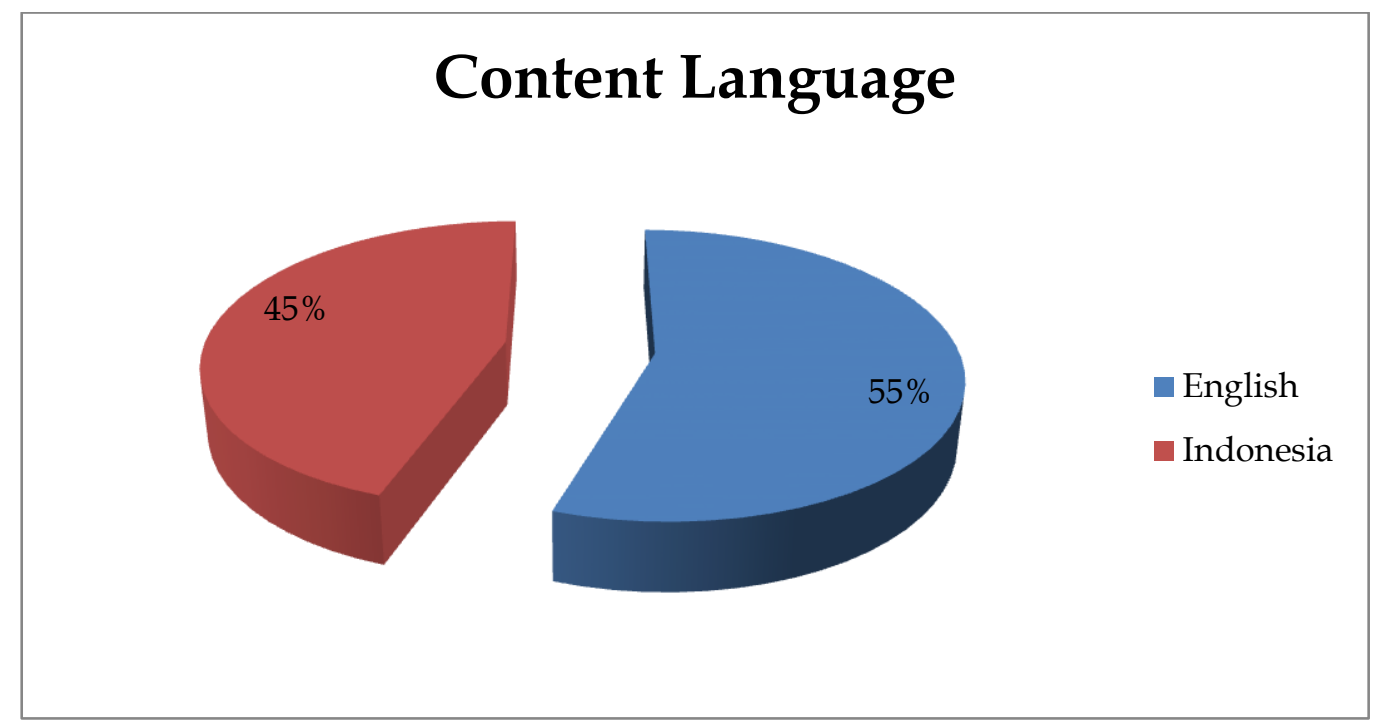

Figure 3. Content Language

Based on the percentage analysis of students' perception on the table 3, the analysis shows that there were no students who states negative statement to the use of YouTube, 19 students $(25 \%)$ were strongly positive who get score in interval 84-100, 53 students (69.74\%) were positive category in interval $68-83$ and 4 students $(5.26 \%)$ were moderate in interval 52-67. The table 3 indicates the implementation of YouTube in teaching is interested to the EFL students. This supported by the following table: 
Table 3. The Percentage of Students' Perception

\begin{tabular}{lrrr}
\hline Category & Range & Frequency & Percentage \\
\hline Strongly Positive & $84-100$ & 19 & $25.00 \%$ \\
Positive & $68-83$ & 53 & $69.74 \%$ \\
Moderate & $52-67$ & 4 & $5.26 \%$ \\
Negative & $36-51$ & 0 & $0.00 \%$ \\
Strongly Negative & $20-35$ & 0 & $0.00 \%$ \\
\hline Total & & 76 & $100.00 \%$ \\
\hline
\end{tabular}

Table 4. The Mean Score of Students' Perception

\begin{tabular}{lll}
\hline Total Respondent & Total of students' score & Mean \\
\hline 76 & 5961 & 78.43 \\
\hline
\end{tabular}

The table 4 shows that the mean score of the students' perception is 78.43 which mean it is in a positive category according to the range of students' perception score. Therefore, the students have positive attitude to the use of YouTube in EFL classroom.

Table 5. Students' Perception Questionnaire Result

\begin{tabular}{llcl}
\hline No. & Statement & Average & Classification \\
\hline 1 & $\begin{array}{l}\text { I like learning English using YouTube because there } \\
\text { are many advantages than other media. }\end{array}$ & 4.41 & Strongly Agree \\
2 & $\begin{array}{l}\text { Learning English using YouTube is ineffective and } \\
\text { inefficient. }\end{array}$ & 2.16 & Disagree \\
3 & $\begin{array}{l}\text { I like learning English using YouTube because the } \\
\text { material is not too difficult to understand. }\end{array}$ & 3.92 & Agree \\
4 & $\begin{array}{l}\text { I dislike YouTube because of expensive access and } \\
\text { waste time. }\end{array}$ & 2.63 & Disagree \\
5 & $\begin{array}{l}\text { During this time I was not happy learning English, } \\
\text { but after studying with YouTube I became happy. }\end{array}$ & 3.41 & Agree \\
6 & $\begin{array}{l}\text { I would rather study normally than use YouTube } \\
\text { because I am sleepy and tired of sitting in front of } \\
\text { the screen. }\end{array}$ & 2.81 & Disagree \\
Through YouTube there are many words that I can \\
know.
\end{tabular}




\begin{tabular}{llcl}
\hline No. & Statement & Average & Classification \\
\hline 12 & $\begin{array}{l}\text { I am making progress in learning English because } \\
\text { YouTube improves reading skills. }\end{array}$ & 3.88 & Agree \\
13 & $\begin{array}{l}\text { I am reluctant to learn English using YouTube } \\
\text { because I do not understand its meaning. }\end{array}$ & 2.09 & Disagree \\
14 & $\begin{array}{l}\text { I like learning English using YouTube because it can } \\
\text { improve my listening skill. }\end{array}$ & 4.30 & Strongly Agree \\
15 & $\begin{array}{l}\text { I dislike learning English using YouTube because it } \\
\text { does not benefit. }\end{array}$ & 1.57 & Strongly Disagree \\
16 & $\begin{array}{l}\text { I like learning English using YouTube because it can } \\
\text { improve my English skills. }\end{array}$ & 4.29 & Strongly Agree \\
17 & $\begin{array}{l}\text { I dislike YouTube in learning English because it } \\
\text { makes me confused to learn the lesson. }\end{array}$ & 2.13 & Disagree \\
\hline $\begin{array}{l}\text { I am very happy to learn English using YouTube } \\
\text { because it can give freedom of thought in terms of } \\
\text { speaking ability. }\end{array}$ & 4.00 & Agree \\
$\begin{array}{l}\text { Learning with using YouTube makes my learning } \\
\text { achievement decrease. }\end{array}$ & 1.96 & Strongly Disagree \\
\hline $\begin{array}{l}\text { I dislike learning English using YouTube because it } \\
\text { does not help me in learning process. }\end{array}$ & 1.88 & Strongly Disagree \\
\hline
\end{tabular}

As seen from the table 5, the students agree that learning English through YouTube is interesting thing because there are many advantages than other media (4.41), help to encourage the students' vocabulary (4.29), enhance the students' listening comprehension (4.3), more understandable because good pronunciation (4), help to improve the students' speaking ability and increase the students' thinking to study (4). In conclusion, according to the average score of the questionnaire 3.92, it is classified as agree. It shows that the students have positive perceptions toward learning English through YouTube. This proved that the use of YouTube videos has a strong effect on the students' mind and senses as supported by [16] who claimed that using YouTube videos can grab students' attention, improve concentration, generate interests in the lessons and improve attitudes towards content. It was relatively easy to gain access to YouTube because it is a well-known video sharing website where users can upload, view and share video clips [1]. According [1] this was also due to the statistical reports on official website those more than one billion visitors every month and thousands of videos and topics in many languages are shared and are available on YouTube.

The literature that was reviewed helped highlight the importance of social media or YouTube as a tool to engage web generation students [23]; [24]. Thus, looking at the findings, it showed that all students were using YouTube to help them learn English and other subjects. With regards to being digitally literate, all the students are connected to technological network and have used YouTube for learning and leisure.

From the finding and explanation above, the researcher can say that the use of YouTube as visual media is applicable for teaching English. It indicated that the positive perceptions of the students to use YouTube in learning English.

\section{Conclusion}

This research showed at the students' perceptions of using YouTube in learning English process in the EFL classroom. This research showed that YouTube may be a viable, innovative and authentic teaching resource. The use of YouTube in EFL classroom is interested to the students. It was proved by the results of students' perception. These scores are categorized as good or positive scores of perceptions if they are confirmed by using a Likert Scale. The result found that there were no students who states negative statement to the use of Facebook, 19 students (25\%) were strongly positive who get score in interval $84-100,53$ students $(69.74 \%)$ were positive category in interval $68-83$ and 4 students $(5.26 \%)$ were moderate in interval 52-67. The mean score of the students' perception is 78.43 which mean it is in a positive category according to the range of students' perception score. However, using YouTube in EFL class to enhance their pronunciation and motivate them to study English outside of class as well as develop some 
degree of learner autonomy remains unclear. Lastly, the researcher concluded that YouTube is a good applicable media in teaching English for EFL students.

\section{Acknowledgements}

I would like to express my appreciation to my mentor Prof. Dr. H. Syarifuddin Dollah, M. Pd for her guidance and encouragement. I am also indebted to the students of English Education Department, Universitas Negeri Makassar for their support and cooperation.

\section{References}

[1] Roodt, S. \& Peier, D. Using YouTube in the classroom for the net generation of students. Issues in Informing Science and Information Technology, 10, 2013, 473-487.

[2] Sakkir G, Rahman Q, Salija K. Students' Perception on Social Media in Writing Class at STKIP Muhammadiyah Rappang, Indonesia. International Journal Of English Linguistics. 2016;6(3):170-5.

[3] Sakkir G. Pengembangan Modul Pengajaran Menulis Berbasis Facebook (Doctoral dissertation, Pascasarjana).

[4] Sakkir, G. (2018). Writing: Beginner. Deepublish. https://books.google.co.id/books?id=2FIVDwAAQBAJ\&printsec=frontcover\&hl=id\#v=onepage \&q\&f=false

[5] Sakkir G, Dollah S. Measuring students'writing skills using Facebook group application in EFL context. International Journal of Humanities and Innovation (IJHI). 2019 Sep 25;293):69-74.

[6] Web Analytics Association. (2006) Google.com tops list of college students' favorite websites- But only through purchase of YouTube.com.

[7] Sharif R. PC skills, English crucial, Kong tells grads. The Star Online.

[8] Fill K, Ottewill R. Sink or swim: taking advantage of developments in video streaming, Innovations in Education and Teaching International, 2018;43, 4, pp $397-408$.

[9] Snelson C. YouTube across the disciplines: A review of the literature. MERLOT Journal of Online Learning and Teaching, 2011;7(1), 159-169.

[10] Sakkir, G. (2016, December). Interest and Writing Skill of the University Students on Using Social Media-Facebook in Writing Class (STKIP Muhammadiyah Rappang, Indonesia). In Asian EFL Journal (Second Language AcquisitionAcademic Research) TESOL Indonesia International Conference Edition (Vol. 2, pp. 178-188).

[11] Rahmhan H, Sakkir G, Khalik S. Audio-Lingual Method to Improve Students's Speaking Skill At Smp Negeri 1 Baranti. La Ogi: English Language Journal. 2020 Jan 31;6(1):15-21.

[12] Sakkir G, Dollah S. Facebook-based writing instructional material in english class: lecturers'perception. Seltics. 2019 Dec 30;2(2):76-83.

[13] Nguyen, N. H. T. \& Tri, D. H. An exploratory study of ICT use in English language learning among EFL university students. Teaching English with Technology, 2014;(4), 32-46.

[14] Sakkir G. The Effectiveness of Pictures In Enhance Writing Skill of Senior High School Students. Interference: Journal of Language, Literature, and Linguistics. 2020 Feb 29;1 \{1).

[15] Gunadevi K. J. S., Fathimah Pathma Abdullah \& Raja Nor Safinas Raja Harun. Polytechnic. 2013.

[16] Berk, R. A. Multimedia teaching with video clips: TV, movies, YouTube, and mtvU in the college classroom. International Journal of Teaching and Learning, 2009;5 (1), 1-21.

[17] Romanelli, F., Bird, E. \& Ryan, M. Learning Styles: A review of theory, application and best practices. American Journal of Pharmaceutical Education. 2009. Retrieved on Jan 2020 from http://www.ncbi.nlm.nih.gov/pmc/articles/PMC2690881/.

[18] Roodt, S. \& De Villiers, C. Using YouTube as an innovative tool for collaborative learning at undergraduate level in tertiary education. Proceedings of the AIS SIG-ED IAIM 2011 Conference. 2011.

[19] Tan, E. \& Pearce, N. Open education videos in the classroom: Exploring the opportunities and barriers to the use of YouTube in teaching introductory sociology. Research in Learning Technology, 2012;19, 128-137.

[20] Ahmad, J.; Basri, M. Implementation of Good Governance in Education Services in Gowa Regency South Sulawesi Province. International Journal of Academic Research, 2015, 7.1.

[21] Rinantanti, Y., Rahman, M. A., Atmowardoyo, H., \& Bin-Tahir, S. Z. Perception of Senior High School EFL Teachers in Papua, Indonesia towards Their Own competence. Journal of Language Teaching and Research, 2017;8(6), 1181-1189.

[22] Ahmad J, S Muliani, Harianti. Millennial Generation And Digitization: Implementation Of Higher Education Functions. International Journal of Scientific \& Technology Research, 2020 Volume 9 - Issue 4.

[23] Sakkir G. Improving Students' Writing Ability through Story Pictures at SMAN 2 Panca Rijang Sidrap (Doctoral 
dissertation, Thesis. Makassar: Graduate Program State University of Makassar).

[24] Sakkir G, Abrar AE. Students' Perception of the Implementation Facebook Group in Learning Writing Skill. In Proceedings of the 65th Teflin International Conference 2018 Nov 19 (Vol. 65, No. 02). 